\title{
Oxalic acid degradation by a novel fungal oxalate oxidase from Abortiporus biennis
}

\author{
Marcin Grąz ${ }^{\circledR}$, Kamila Rachwał’2, Radosław Zan² and Anna Jarosz-Wilkołazka' \\ 'Department of Biochemistry, Maria Curie-Skłodowska University, Lublin, Poland; 2Department of Genetics and Microbiology, \\ Maria Curie-Skłodowska University, Lublin, Poland
}

\begin{abstract}
Oxalate oxidase was identified in mycelial extracts of a basidiomycete Abortiporus biennis strain. Intracellular enzyme activity was detected only after prior lowering of the $\mathrm{pH}$ value of the fungal cultures by using oxalic or hydrochloric acids. This enzyme was purified using size exclusion chromatography (Sephadex G-25) and ion-exchange chromatography (DEAE-Sepharose). This enzyme exhibited optimum activity at $\mathrm{pH} 2$ when incubated at $40^{\circ} \mathrm{C}$, and the optimum temperature was established at $60^{\circ} \mathrm{C}$. Among the tested organic acids, this enzyme exhibited specificity only towards oxalic acid. Molecular mass was calculated as $58 \mathrm{kDa}$. The values of $K_{\mathrm{m}}$ for oxalate and $V_{\max }$ for the enzyme reaction were $0.015 \mathrm{M}$ and $30 \mathrm{mmol} \mathrm{min}^{-1}$, respectively.
\end{abstract}

Key words: oxalate oxidase, oxalic acid, Abortiporus biennis

Received: 04 March, 2016; revised: 25 April, 2016; accepted: 20 May, 2016; available on-line: 23 June, 2016

\section{INTRODUCTION}

Abortiporus biennis is a ligninolytic basidiomycete fungus belonging to the ecological group of white rot fungi that are very efficient natural wood degraders. These fungi possess a unique system for efficient degradation of a lignin polymer which constitutes the major carbon source on Earth. The main constituents of this system are extracellular enzymes, like laccase and different peroxidases - manganese-dependent peroxidase $(\mathrm{MnP})$, lignin peroxidase $(\mathrm{LiP})$, and versatile peroxidase (VP) (Jarosz-Wilkołazka et al., 2008; Polak \& Jarosz-Wilkołazka, 2012). Enzymatic degradation of lignin is supported in multiple ways by the action of low-molecular-weight compounds (Kaneko et al., 2005), and among them, a very important role is played by oxalic acid. This dicarboxylic acid is a predominant organic acid secreted by many fungi and has several ecological roles, e.g. facilitation of the $\mathrm{MnP}$ action by chelating unstable $\mathrm{Mn}^{3+}$ ions or buffering $\mathrm{pH}$ values outside the hyphae (Hofrichter, 2002). The biosynthesis of oxalic acid in fungi most likely implicates the tricarboxylic acid cycle, involving the hydrolytic cleavage of oxaloacetate to acetate and oxalate, or the glyoxylate cycle involving oxidation of glyoxylate to oxalate (Mäkelä et al., 2010). There is diversity in secretion of oxalic acid among varied ecological groups of wood degrading fungi. Brown rot fungi generally secrete oxalic acid in higher amounts than white rot fungi (Hastrup et al., 2012; Mäkelä et al., 2010). This can be due to the fact that white rot fungi are able to decompose oxalic acid via the action of oxalate decarboxylase (EC 4.1.1.2), which converts oxalate to formic acid and carbon dioxide (Mäkelä et al., 2002). The degradation of oxalate via action of oxalate oxidase (EC 1.2.3.4), described in our study, is atypical for fungi and was found predominantly in higher plants. The best characterised oxalate oxidase originates from cereal plants (Dunwell, 2000). Currently, only three oxalate oxidases of basidiomycete fungi have been described - an enzyme from Tilletia contraversa (Vaisey et al., 1961), the best characterised so far enzyme from Ceriporiopsis subvermispora (Aguilar et al., 1999), and an enzyme produced by Abortiporus biennis (Graz et al., 2009). The enzyme from C. subvermispora was also expressed in Pichia pastoris and characterised as $\mathrm{Mn}(\mathrm{II})$-containing bicupin protein sharing homology with bicupin microbial oxalate decarboxylase (Moussatche et al., 2011). Oxalate oxidase decomposes oxalic acid to carbon dioxide and hydrogen peroxide. Hydrogen peroxide is in turn the key component of the catalytic cycle of all peroxidases and can also be generated by fungal feedback-type enzymes, like glucose1-oxidase (EC 1.1.3.4), aryl alcohol oxidases (EC 1.1.3.7), and pyranose-2-oxidase (EC 1.1.3.10) (Leonowicz et al., 1999). Oxalic acid also plays a significant role in biological and geochemical processes in the soil (Gadd, 2007). For example, oxalate has a large effect on the availability of phosphorous and calcium, and is associated with weathering of soil minerals and precipitation of insoluble metal oxalates (Jarosz-Wilkołazka \& Grąz, 2006, JaroszWilkołazka et al., 2006, Grąz et al., 2009). Oxalic acid is a known toxic compound associated with plant pathogenic fungal strains, such as Sclerotinia sclerotiorum (Hegedus \& Rimmer, 2005). The level of oxalic acid is also an important factor in many technologies applied in the industry, such as the paper industry or brewing processes (Dunwell et al., 2000, Sjöde et al., 2008).

In this study, we examined factors influencing the induction of the oxalate oxidase activity in cultures of white rot fungus Abortiporus biennis and characterised selected properties of the novel fungal oxalate oxidase (OXOAb).

\section{MATERIALS AND METHODS}

The organism and growth conditions. Abortiporus biennis was obtained from the Fungal Collection of the Biochemistry Department, Maria Curie-Skłodowska University, Lublin, Poland. Stock cultures were maintained on $2 \%$ malt extract agar (MEA) slants at $4^{\circ} \mathrm{C}$. The inoculum was pre-cultured on $2 \%$ MEA for one

e-mail: graz@umcs.lublin.pl

Abbreviations: OXO, oxalate oxidase; OXOAb, oxalate oxidase from Abortiporus biennis 
week at $25^{\circ} \mathrm{C}$. The experiments were performed in Erlenmeyer flasks using liquid medium containing glucose $\left(10 \mathrm{~g} \mathrm{~L}^{-1}\right)$ and potato extract $\left(4 \mathrm{~g} \mathrm{~L}^{-1}\right)$. The inoculated flasks were incubated at $25^{\circ} \mathrm{C}$ with a rotation mode $(160 \mathrm{rpm})$. After 7 days of cultivation, OXOAb production by the $A$. biennis strain was induced by addition of oxalic acid, sodium oxalate, or hydrochloric acid (to the final concentration of $10 \mathrm{mM}$ ) to the growth media. After 24 hours, the mycelium was harvested and homogenised. The mycelial extract was centrifuged, assayed for the OXOAb activity, and frozen for further analysis.

Oxalate oxidase activity (OXOAb) assay (Aguilar et al., 1999). The standard assay of this enzyme was based on the measurement of enzymatically generated hydrogen peroxide. The reaction mixture contained $0.3 \mathrm{~mL}$ of $20 \mathrm{mM}$ oxalic acid in $0.05 \mathrm{M}$ succinate buffer, pH 3.5, and $0.2 \mathrm{~mL}$ of the enzyme. After incubation of the reaction mixture for $15 \mathrm{~min}$ at $40^{\circ} \mathrm{C}, 0.45 \mathrm{~mL}$ of $0.2 \mathrm{mM}$ phenol red solution and $0.05 \mathrm{~mL}$ of horseradish peroxidase $(6.25 \mathrm{U})$ in $0.05 \mathrm{M}$ succinate buffer, pH 3.5, were added. Following incubation at $30^{\circ} \mathrm{C}$ for $15 \mathrm{~min}, 0.1 \mathrm{~mL}$ of $5 \mathrm{M} \mathrm{NaOH}$ was added and the absorbance at $610 \mathrm{~nm}$ was measured. A standard curve was used to calculate the amount of $\mathrm{H}_{2} \mathrm{O}_{2}$ (prepared in $0.05 \mathrm{M}$ succinate buffer) generated during the OXOAb reaction. One enzyme unit was defined as the amount of enzyme required to produce $1 \mathrm{mmol}$ of $\mathrm{H}_{2} \mathrm{O}_{2}$ per minute, under standard assay conditions.

To determine the optimum $\mathrm{pH}$ value for OXOAb activity, the enzyme was incubated with oxalic acid in $0.05 \mathrm{M}$ succinate buffer of $\mathrm{pH} 2,2.5,3,3.5$, and 4 . The optimum temperature for OXOAb activity was determined using succinate buffer $\mathrm{pH} 3.5$ and incubation at $30^{\circ} \mathrm{C}, 40^{\circ} \mathrm{C}, 50^{\circ} \mathrm{C}, 60^{\circ} \mathrm{C}, 70^{\circ} \mathrm{C}$, and $80^{\circ} \mathrm{C}$. To determine the substrate specificity of OXOAb, the standard activity assay was performed using citric, malic, malonic, glycolic, glioxalic, succinic, and acetic acids at $2 \mathrm{mM}$ and $20 \mathrm{mM}$ concentrations at $\mathrm{pH} 3.5$. The $K_{\mathrm{m}}$ and $V_{\max }$ values were determined using standard conditions of the reaction.

Determination of protein concentration. Protein concentration was determined using the Bradford method (1976) and bovine serum albumin was used as a standard.

Determination of hydrogen peroxide concentration. The chemiluminescence method based on the Co (II)-catalysed oxidation of luminol by $\mathrm{H}_{2} \mathrm{O}_{2}$ was applied according to Perez and Rubio (2006).

Determination of organic acid concentration. The concentration of organic acids in the cultures of $A$. biennis was monitored by capillary electrophoresis using an Agilent 7100 Capillary Electrophoresis System equipped with a UV-Vis detector. The separation was carried out using a fused silica capillary $50 \mu \mathrm{m}$ ID with a $50 \mathrm{~cm}$ length to the detection window. The voltage applied was $-25 \mathrm{kV}$ and the capillary temperature was maintained at $15^{\circ} \mathrm{C}$. Samples were injected hydrodynamically for $5 \mathrm{~s}$ (50 mbar) and organic acid was detected by indirect UVdetection at a wavelength of $350 \mathrm{~nm}$ (bandwidth $20 \mathrm{~nm}$ ) and a reference wavelength of $230 \mathrm{~nm}$ (bandwidth 10 $\mathrm{nm}$ ). The buffer solution was freshly prepared every day by dissolving phthalic acid $(5 \mathrm{mM})$, cetyltrimethylammonium bromide (CTAB, $0.26 \mathrm{mM})$, and methanol $(0.5 \%$ $\mathrm{v} / \mathrm{v}$ ) in MiliQ water (Chen et al., 1997). Peak identification was done by spiking with commercially available formic and oxalic acids.

Enzyme purification. Gel filtration on Sephadex G-25. The crude extract obtained after homogenization and centrifugation of induced mycelium of $A$. biennis was loaded onto a Sephadex G-25 column $(2.5 \times 30 \mathrm{~cm})$ previously equilibrated with $20 \mathrm{mM}$ phosphate buffer $\mathrm{pH}$ 6.5. The column was eluted with $20 \mathrm{mM}$ phosphate buffer, $\mathrm{pH} 6.5$, at a flow rate of $0.5 \mathrm{~mL} / \mathrm{min}$ and $5-\mathrm{mL}$ fractions were collected and monitored for protein and OXOAb activity.

Ion exchange chromatography on DEAE-Sepharose. Protein fractions with OXOAb activity collected after gel filtration were loaded onto a DEAESepharose column equilibrated with $20 \mathrm{mM}$ phosphate buffer, $\mathrm{pH}$ 6.7. The bound proteins were eluted with a linear gradient of $\mathrm{NaCl}(0-75 \%)$ in $20 \mathrm{mM}$ phosphate buffer, $\mathrm{pH}$ 6.7. The $3-\mathrm{mL}$ fractions were collected at the flow rate of $1 \mathrm{~mL} / \mathrm{min}$ and tested for protein and OXOAb activity. The active fractions were pooled, desalted using ultrafiltration, and stored at $-20^{\circ} \mathrm{C}$.

Polyacrylamide gel electrophoresis. SDS-PAGE was performed according to the method of Laemmli (1970), using $12 \%$ running gel and 5\% stacking gel of polyacrylamide. The proteins were silver stained. The molecular weight was calculated using SynGene GeneTools. For the determination of the activity, the SDS was omitted and $9 \%$ running gel was prepared. The staining procedure comprised incubation with oxalic acid as a substrate and subsequent incubation with 2,6-dimethoxyphenol and horseradish peroxidase.

\section{RESULTS}

\section{Degradation of oxalic acid in A. biennis cultures}

In the tested $A$. biennis cultures, oxalate oxidase (OXOAb) activity was observed only after exogenous addition of oxalic acid as an inductor to the growth media. To confirm the way of oxalic acid degradation by $A$. biennis, the presence of formic acid in the growth media as a product of decarboxylation of oxalate, and the presence of hydrogen peroxide as a product of oxalic acid oxidation by oxalate oxidase, were tested. As shown in Fig. $1, \mathrm{H}_{2} \mathrm{O}_{2}$ was detected in the growth media of $A$. biennis as the main product of oxalic acid degradation after 24 hours of induction. This suggests an oxidative activity of $A$. biennis towards oxalic acid catalysed by oxalate oxidase. Only

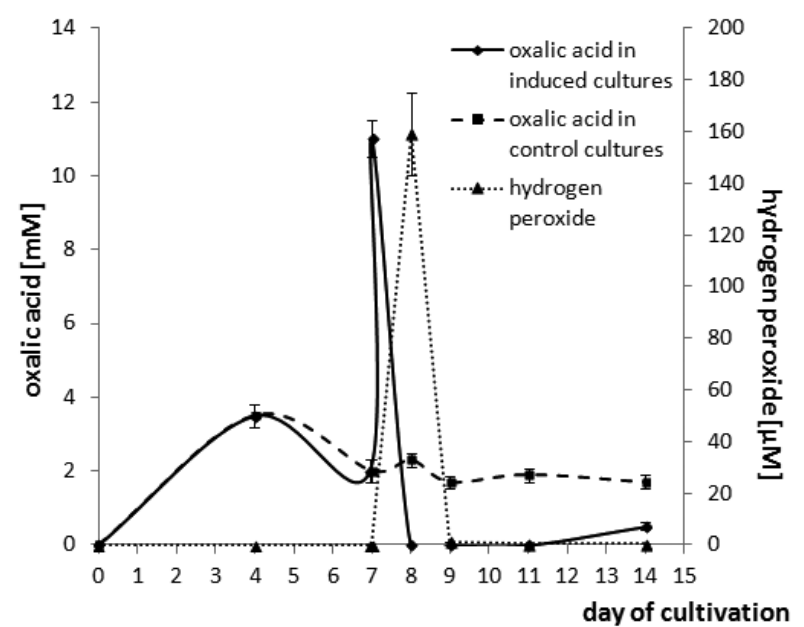

Figure 1. Oxalic acid degradation and hydrogen peroxide appearance after exogenous addition of oxalic acid on the $7^{\text {th }}$ day of $A$. biennis growth. 


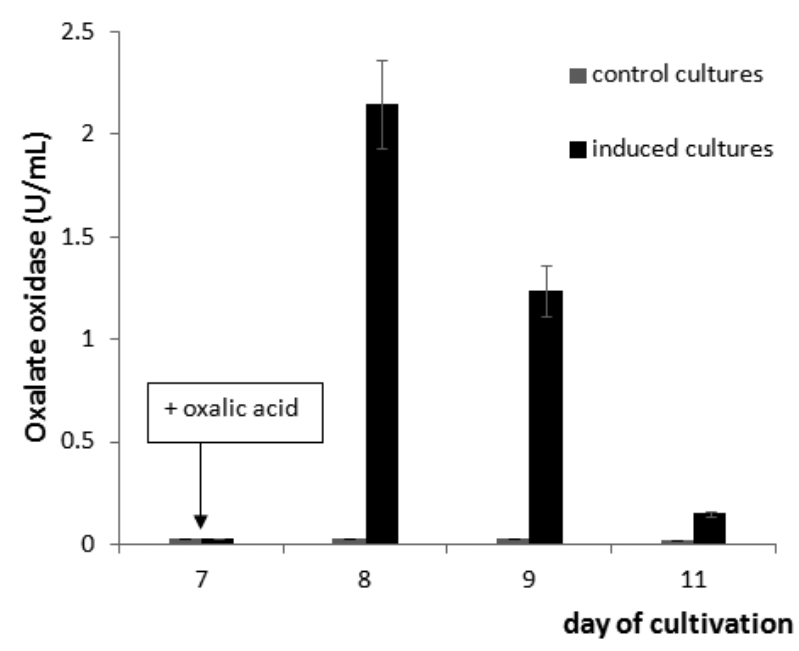

Figure 2. Intracellular oxalate oxidase activity in the control and induced with oxalic acid (final concentration $10 \mathrm{mM}$ ) cultures of A. biennis.

The arrow indicates the day of the inductor addition.

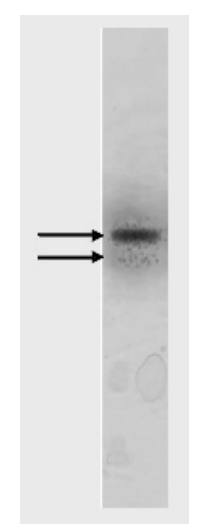

Figure 3. PAGE stained for oxalate oxidase activity.

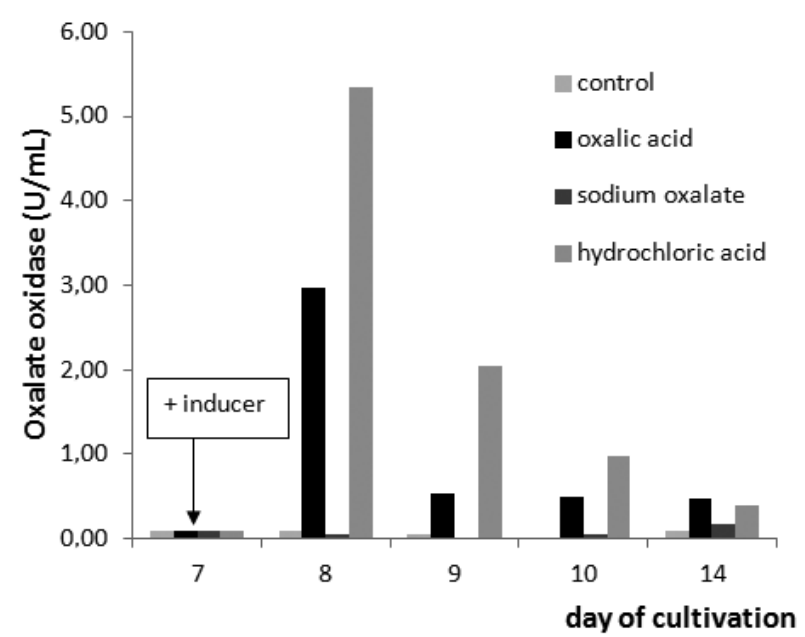

Figure 4. The effect of $A$. biennis culture supplementation with inducers (oxalic acid, sodium oxalate or hydrochloric acid) on OXOAb activity in mycelia.

The arrow indicates the day of the inductor addition. Control was set up without any inducer addition.

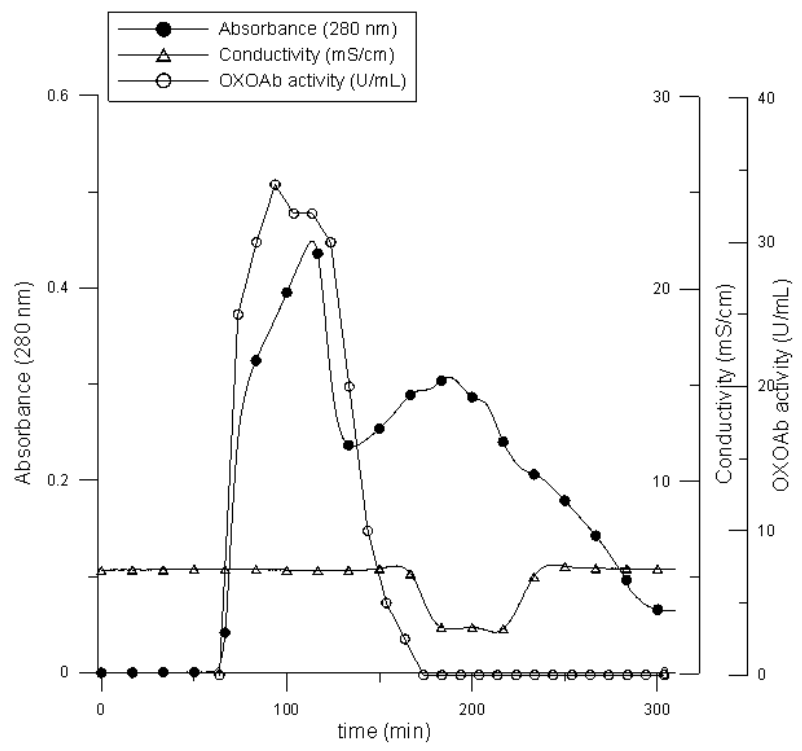

Figure 5. Elution profile of OXOAb activity obtained after size exclusion chromatography on Sephadex G-25.

intracellular activity of OXOAb was detected after induction of $A$. biennis cultures with oxalic acid (Fig. 2). No extracellular oxalate oxidase activity was detected in the growth media. Native intracellular OXOAb was visualised as two protein bands in a polyacrylamide gel, as presented in Fig. 3.

\section{Factors influencing oxalate oxidase production by A. biennis}

To specify if the expression of oxalate oxidase in A. biennis mycelium was induced by oxalic acid - the substrate of the enzyme, or by lowering the $\mathrm{pH}$ value of the growth media, a solution of oxalic acid, sodium oxalate, and $\mathrm{HCl}$ were added separately to the cultures of $A$. biennis as inductors. As shown in Fig. 4, the activity of $A$. biennis oxalate oxidase was detected in the mycelium of cultures induced by oxalic acid and $\mathrm{HCl}$, but was not detected in cultures induced by addition of sodium oxalate. This indicates that the lowering of the $\mathrm{pH}$ value is sufficient for induction of oxalate oxidase activity during the growth of $A$. biennis.

\section{Purification of oxalate oxidase from A. biennis}

The mycelium of $A$. biennis from the culture induced with oxalic acid was homogenised and the OXO-specific activity was detected in the supernatant after centrifugation. The supernatant (the crude extract of OXOAb) was loaded onto a Sephadex G-25 column. After chromatography, the OXOAb activity was detected in the first peak (Fig. 5). The next step of the purification procedure was performed on a DEAE-Sepharose column and the elution profile is presented in Fig. 6. Fractions with the high activities of OXOAb were collected and desalted. The enzyme was finally purified 11.1 fold, with $1.7 \%$ recovery, when compared to the crude extract (Table 1). After size exclusion and ion-exchange chromatography, the collected fractions exhibiting OXOAb activities were analysed by SDS-PAGE, which revealed a band of protein with a molecular size calculated as $58 \mathrm{kDa}$ (Fig. 7). 


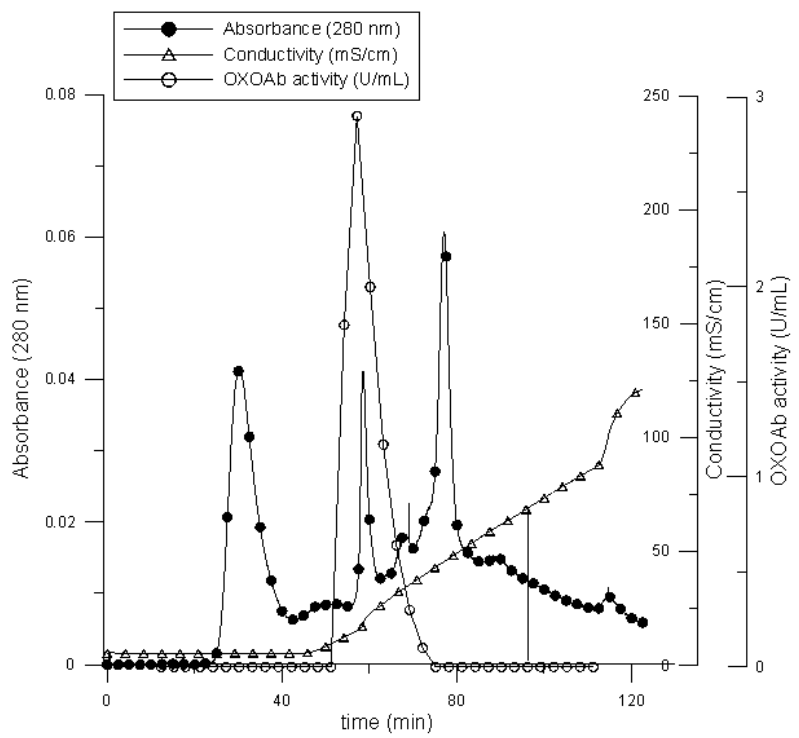

Figure 6. Elution profile of OXOAb activity obtained after ion exchange chromatography on DEAE-Sepharose.

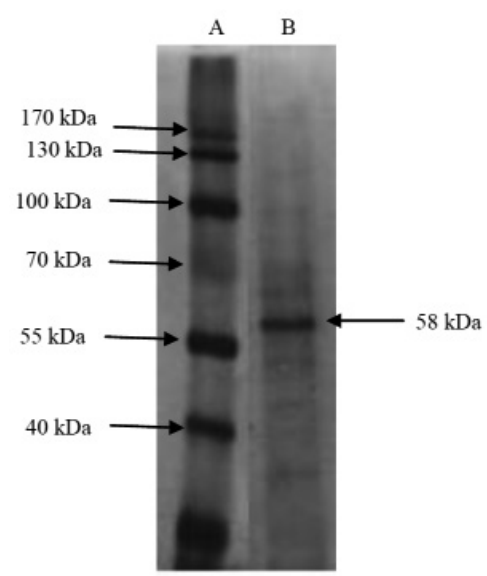

Figure 7. SDS-PAGE of OXOAb active fractions obtained after the purification procedure; lane $A$, protein marker; lane B, enzyme fraction obtained after chromatography on DEAE-Sepharose.

\section{Properties of OXOAb}

The optimum $\mathrm{pH}$ value for $\mathrm{OXOAb}$ activity was assayed in the $\mathrm{pH}$ range between 2 and 4 . OXOAb displayed a maximum activity at $\mathrm{pH} 2$, when incubated at $40^{\circ} \mathrm{C}$. This activity decreased with the increasing $\mathrm{pH}$ and was almost gone at $\mathrm{pH} 4$ (Fig. 8). The optimum temperature for oxidation of oxalic acid by OXOAb

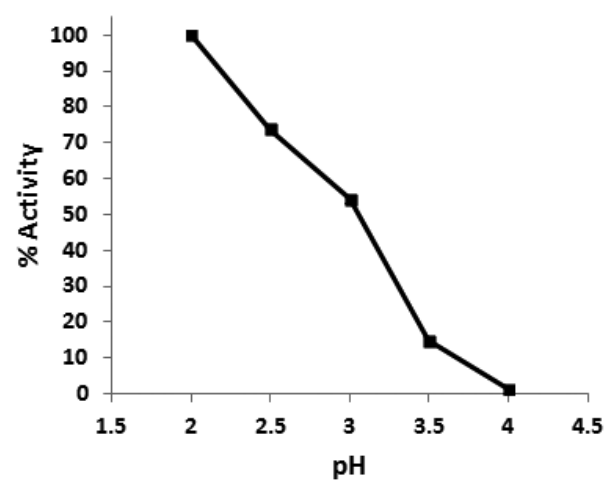

Figure 8. The effect of $\mathrm{pH}$ values on OXOAb activity. The activity of OXOAb measured at $\mathrm{pH} 2$ was taken as $100 \%$.

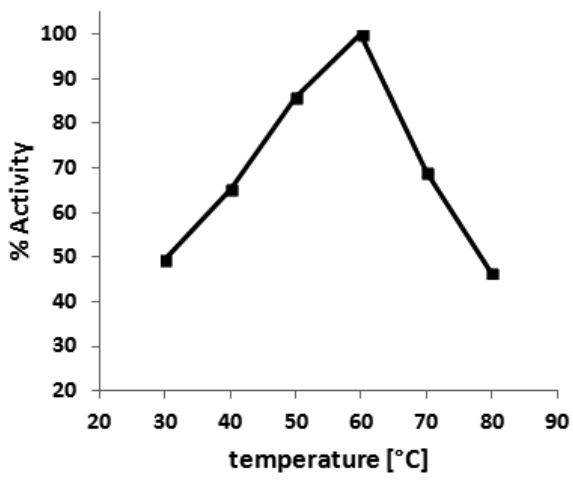

Figure 9. The effect of the temperature range $\left(30-80^{\circ} \mathrm{C}\right)$ on OXOAb activity.

The activity of OXOAb measured at $60^{\circ} \mathrm{C}$ was taken as $100 \%$.

is presented in Fig. 9. When OXOAb was assayed at temperatures in the range from $30^{\circ} \mathrm{C}$ to $80^{\circ} \mathrm{C}$, the highest activity was found at $60^{\circ} \mathrm{C}$. To determine substrate specificity, several organic acids, including citric, malic, malonic, glycolic, glioxalic, succinic, and acetic acid, were used as pSossible substrates for OXOAb. None of the tested carboxylic acids were oxidised by the OXOAb. The effect of the oxalic acid concentration on the initial velocity of the enzyme reaction was tested. The $V_{\max }$ of the enzyme was achieved at 0.03 mol $\mathrm{min}^{-1}$. The $K_{\mathrm{m}}$ value for oxalic acid was found to be $0.015 \mathrm{M}$.

\section{DISCUSSION}

In this study, we tested the liquid cultures of $A$. biennis to confirm the unique ability of this fungus to degrade oxalic acid by oxidation. In our earlier study, we

Table 1. Summary of the purification procedure of OXOAb.

\begin{tabular}{|c|c|c|c|c|c|c|c|}
\hline Fraction & $\begin{array}{l}\text { Volume } \\
(\mathrm{mL})\end{array}$ & $\begin{array}{l}\text { Protein } \\
\text { (mg) }\end{array}$ & $\begin{array}{l}\text { Activity } \\
(\mathrm{U} / \mathrm{mL})\end{array}$ & $\begin{array}{l}\text { Total activity } \\
\text { (U) }\end{array}$ & $\begin{array}{l}\text { Specific activity } \\
(\mathrm{U} / \mathrm{mg})\end{array}$ & $\begin{array}{l}\text { Purification } \\
\text { (fold) }\end{array}$ & $\begin{array}{l}\text { Yield } \\
(\%)\end{array}$ \\
\hline Crude extract & 60 & 706.2 & 28 & 1680 & 2.4 & 1 & 100 \\
\hline Gel filtration (Sephadex G-25) & 20 & 105 & 34 & 680 & 6.5 & 2.7 & 40.5 \\
\hline $\begin{array}{l}\text { lon exchange chromatography } \\
\text { (DEAE-Sepharose) }\end{array}$ & 10 & 1.1 & 2.9 & 28.7 & 26.3 & 11.1 & 1.7 \\
\hline
\end{tabular}


described enhanced oxalate oxidase activity in $A$. biennis in the presence of metal oxides (Graz et al., 2009). Decarboxylation of oxalic acid by oxalate decarboxylase in basidiomycete fungi is typical and well described (Kesarwani et al., 2000; Mäkelä et al., 2002; Mäkelä et al., 2010). The oxidative way of oxalic acid decomposition is atypical for basidiomycete fungi and has been so far described only in Ceriporiopsis subvermispora (Aguilar et al., 1999) and Tilletia contraversa (Vaisey et al., 1961). Oxalic acid can be degraded by oxalate decarboxylase (EC 4.1.1.2) occurring in fungi, by oxalyl-CoA decarboxylase (EC 4.1.1.8) detected in bacteria, and by oxalate oxidase (EC 1.2.3.4) observed in plants (Svedružić et al., 2005). This rigid division of oxalate decomposition activities is now unsettled because of the latest reports concerning fungal oxalate oxidase from C. subvermispora (Aguilar et al., 1999) and oxalate oxidase from $A$. biennis, as well as plant oxalyl-CoA decarboxylase found in Arabidopsis (Foster et al., 2012). Oxalate oxidase and oxalate decarboxylase are members of the cupin superfamily of proteins. All so far described oxalate oxidases from plants (also known as germins) are classified as monocupins (Dunwell, 2000; Svedružić et al., 2005). The best characterised and purified fungal oxalate oxidase from $C$. subvermispora revealed the oxalate decarboxylase side reaction and was unexpectedly classified as a bicupin protein, the same as all known fungal oxalate decarboxylases (Escutia et al., 2005). The specific activity of purified C. subvermispora enzyme expressed in $P$. pastoris showed direct correlation with manganese ions content. Under methanol-induced expression, oxalate oxidase was secreted into the growth media as a soluble and functional enzyme, which is in contrast to the native intracellular enzyme from C. subvermispora. The $\mathrm{pH}$ optimum was similar and amounted to $\mathrm{pH} 3.5$ for the native protein, and 4.0 for an enzyme expressed in $P$. pastoris. It was suggested that the recombinant protein was inhibited by succinate and by citrate in a competitive and uncompetitive manner, respectively (Moussatche et al., 2011). It was also demonstrated that bacterial oxalate decarboxylase from B. subtilis can be converted into an oxidase by mutation in the active site of the enzyme (Burrell et al., 2007). In our study, we have found oxalate oxidase activity (OXOAb) in $A$. biennis mycelium after induction of this enzyme with oxalic acid or $\mathrm{HCl}$. To detect the OXOAb activity in $A$. biennis, only reduction of the $\mathrm{pH}$ value of the growth media was required. Known fungal oxalate decarboxylases have an inducible character, like an oxalate decarboxylase from basidiomycete Flammulina velutipes induced by oxalic acid (Azam et al., 2002), or an enzyme from Trametes versicolor induced by both, oxalic acid and inorganic acids (Zhu \& Hong, 2010). Mäkelä and co-workers (2009) found a rather constitutive expression of an oxalate decarboxylase in Dichomitus squalens after addition of oxalic acid stimulating oxalate decarboxylase activity, but no increase in the transcript amount was observed, which suggests activation rather than transcriptional upregulation of the enzyme. The rapid degradation rate of oxalic acid by $A$. biennis observed in this study could also suggest the activation of the already existing enzyme rather than the induction process, but this hypothesis requires further studies.

All known oxalate degrading enzymes possess optimum activity at low $\mathrm{pH}$ values. The OXOAb was active only at acidic $\mathrm{pH}$ values below $\mathrm{pH} 4$, with the highest activity at $\mathrm{pH}$ 2. A similar optimum $\mathrm{pH}$ value $(\mathrm{pH} 2.6)$ was described for OXO from Tilletia contraversa (Vaisey et al., 1961). The oxalate oxidase from C. subvermispora showed its maximum activity at $\mathrm{pH} 3.5$, similar to known plant enzymes which exhibited their $\mathrm{pH}$ optima in the acidic range varying between $\mathrm{pH} 3.2$, reported for maize roots (Velutić \& Sulković, 2000), pH 3.5 for Amaranthus spinosus leaves (Goyal et al., 1999) and wheat seedlings (Hu \& Guo, 2009), to pH 5 for Sorghum leaves (Pundir \& Nath, 1984).

In our study, the optimum temperature for OXOAb activity was $60^{\circ} \mathrm{C}$. OXOAb retained $20 \%$ of its initial activity after 15 minutes of pre-incubation at $60^{\circ} \mathrm{C}$, and only $5 \%$ of its initial activity after pre-incubation at $80^{\circ} \mathrm{C}$ (data not shown). This indicates a protective character of the substrate on the active site of the enzyme. The optimum activity for fungal oxalate oxidase from $C$. subvermispora was obtained at $40^{\circ} \mathrm{C}$ (Aguilar et al., 1999). Plant enzymes showed their optimum temperatures at $40^{\circ} \mathrm{C}$ for OXO from A. spinosus (Goyal et al., 1999), and $37^{\circ} \mathrm{C}$ for the enzyme from barley roots (Kotsira \& Clonis, 1997). Plant enzymes reveal higher thermal stability, e.g. strawberry fruit oxalate oxidase retained $76 \%$ of its initial activity after incubation at $80^{\circ} \mathrm{C}$ for 30 minutes (Dahiya et al., 2010).

Among the tested organic acids, OXOAb oxidised only oxalic acid. The $K_{\mathrm{m}}$ value for oxalate was found to be $1.5 \times 10^{-2} \mathrm{M}$ and the $V_{\max }$ value was $0.03 \mathrm{~mol} \mathrm{~min}^{-1}$. These parameters are higher than those found for oxalate oxidase from the $C$. subvermispora fungus which has $K_{\mathrm{m}}$ for oxalate of $1 \times 10^{-4} \mathrm{M}$ and was inhibited at an oxalic acid concentration above $2.5 \mathrm{mM}$. Known oxalate oxidases from plants revealed different values of $K_{\mathrm{m}}$ for oxalate degradation, e.g. it was $1.67 \times 10^{-3} \mathrm{M}$ for a strawberry fruit enzyme (Dahiya et al., 2010), $2.1 \times 10^{-4} \mathrm{M}$ for an enzyme from wheat seedlings (Hu and Guo, 2009), and $2.16 \times 10^{-3} \mathrm{M}$ for OXO from Amaranthus leaves (Goyal et al., 1999). Oxalate oxidases isolated from plants are multimeric proteins (Svedružić et al., 2005). The molecular weight of fungal oxalate oxidase from $C$. subvermispora was $400 \mathrm{kDa}$ and was suggested to be a homohexameric enzyme. The molecular weight of $58 \mathrm{kDa}$ observed for $\mathrm{OXOAb}$ in this study (SDS-PAGE) corresponds to the molecular weight of a monomer of oxalate oxidase from C. subvermispora determined as $65.5 \mathrm{kDa}$ (Aguilar et al., 1999).

\section{CONCLUSIONS}

Searching for novel enzymes with potentially divergent properties from those described so far seems to be well justified because oxalate-degrading enzymes have a great potential in various biotechnological and diagnostic applications. Oxalate oxidase from Abortiporus biennis represents a unique catalytic activity in basidiomycete fungi. In our opinion, development of knowledge in the field of plant and microorganism enzymatic regulation of the level of oxalate in the environment could contribute to progress in the field of bioremediation, geomycology, and agriculture.

\section{Acknowledgements}

This work was supported by the National Science Centre, Poland (2014/13/B/NZ9/02106).

\section{REFERENCES}

Aguilar C, Urzúa U, Koenig C, Vicňa R (1999) Oxalate oxidase from Ceriporiopsis subvermispora: biochemical and cytochemical study. Arch Biochem Biophys 366: 275-282.

Azam M, Kesarwani M, Chakraborty S, Natarajan K, Datta A (2002) Cloning and characterization of the 5'-flanking region of the oxalate decarboxylase gene from Flammulina velutipes. Biochem J 367: 67-75. 
Bradford MM (1976) A rapid and sensitive method for the quantitation of microgram quantities of protein utilizing the principle of protein-dye binding. Anal Biochem 72: 248-254.

Burrell MR, Just VJ, Bowater L, Fairhurst SA, Requena L, Lawson DM, Bornemann S (2007) Oxalate decarboxylase and oxalate oxidase activities can be interchanged with a specificity switch of up to 282000 by mutating an active site lid. Biochemistry 46: 12327-12336. DOI: $10.1021 /$ bi700947s.

Chen J, Preston BP, Zimmerman MJ (1997) Analysis of organic acids in industrial samples. Comparison of capillary electrophoresis and ion chromatography. J Chromatogr A 781: 205-213. DOI: 10.1016/ S0021-9673(97)00374-9.

Dahiya T, Yadav S, Chauhan N, Handa P, Pundir CS (2010) Strawberry fruit oxalate oxidase - detection, purification, characterization and physiological role. J Plant Biochem Biotechnol 19: 247-250. DOI: 10.1007/BF03263349.

Dunwell JM, Khuri S, Gane PJ (2000) Microbial relatives of the seed storage proteins of higher plants: conservation of structure and diversification of function during evolution of the cupin superfamily. Microbiol Mol Biol Rev 64: 153-179. DOI: 10.1128/MMBR.64.1.153179.2000 .

Escutia MR, Bowater L, Edwards A, Bottrill AR, Burrell MR, Polanco R, Vicuna R, Bornemann S (2005) Cloning and sequencing of two Ceriporiopsis subvermispora bicupin oxalate oxidase allelic isoforms: implications for the reaction specificity of oxalate oxidase and decarboxylases. Appl Env Microbiol 71: 3608-3616. DOI: 10.1128/ AEM.71.7.3608-3616.2005.

Foster J, Kim HU, Nakata PA, Browse J (2012) A previously unknown oxalyl-CoA synthetase is important for oxalate catabolism in Arabidopsis. The Plant Cell 24: 1217-1229. DOI: 10.1105/tpc.112.096032.

Gadd GM (2007) Geomycology: biogeochemical transformations of rocks, minerals, metals and radionuclides by fungi, bioweathering and bioremediation. Mycol Res 111: 3-49. DOI: 10.1016/j.mycres.2006.12.001.

Goyal L, Thakur M, Pundir CS (1999) Purification and properties of a membrane bound oxalate oxidase from Amaranthus leaves. Plant S $i$ 142: $21-28$.

Grąz M, Jarosz-Wilkołazka A, Pawlikowska-Pawlęga B (2009) Abortiporus biennis tolerance to insoluble metal oxides: oxalate secretion, oxalate oxidase activity, and mycelial morphology. Biometals 22: 401410. DOI 10.1007/s10534-008-9176-1.

Hastrup ACS, Green III F, Lebow PK, Jensen B (2012) Enzymatic oxalic acid regulation correlated with wood degradation in four brown-rot fungi. Int Biodeter Biodegr 75: 109-114. DOI:10.1016/j. ibiod.2012.05.030.

Hegedus DD, Rimmer SR (2005) Sclerotinia sclerotiorum: when "to be or not to be" a pathogen? FEMS Microbiol Lett 251: 177-184. DOI: 10.1016/j.femsle.2005.07.040.

Hofrichter M (2002) Review: lignin conversion by manganese peroxidase (MnP). Enz Microb Technol 30: 454-466. DOI: 10.1016/S01410229(01)00528-2.

$\mathrm{Hu} \mathrm{Y,} \mathrm{Guo} \mathrm{Z} \mathrm{(2009)} \mathrm{Purification} \mathrm{and} \mathrm{characterization} \mathrm{of} \mathrm{oxalate} \mathrm{oxi-}$ dase from wheat seedlings. Acta Physiol Plant 31: 229-235. DOI: 10.1007/s11738-008-0222-y.

Jarosz-Wilkołazka A, Grąz M, Braha B, Menge S, Schlosser D, Krauss GJ (2006) Species-specific Cd-stress response in the white rot basidiomycetes Abortiporus biennis and Cerrena unicolor. Biometals 19: 39-49. DOI 10.1007/s10534-005-4599-4.

Jarosz-Wilkołazka A, Grąz M (2006) Organic acid production by white rot basidiomycetes in the presence of metallic oxides. Can J Microbiol 52: 779-785. DOI: 10.1139/W06-032.

Jarosz-Wilkołazka A, Luterek J, Olszewska A (2008) Catalytic activity of versatile peroxidase from Bjerkandera fumosa at different $\mathrm{pH}$. Biocatal Biotransfor 26: 280-287. DOI: 10.1080/10242420701830082.

Jaszek M, Grzywnowicz K, Malarczyk E, Leonowicz A (2006) Enhanced extracellular laccase activity as a part of the response sys- tem of white rot fungi: Trametes versicolor and Abortiporus bennis to paraquat-caused oxidative stress conditions. Pest Biochem Physiol 85: 147-154. DOI: 10.1016/j.pestbp.2006.01.002.

Kaneko S, Yoshitake K, Itakura S, Tanaka H, Enoki A (2005) Relationship between production of hydroxyl radicals and degradation of wood, crystalline cellulose, and lignin-related compound or accumulation of oxalic acid in cultures of brown-rot fungi. $J$ Wood Sci 51: 262-269. DOI 10.1007/s10086-004-0641-3.

Kesarwani M, Azam M, Natarajan K, Mehta A, Datta A (2000) Oxalate decarboxylase from Collybia velutipes. J Biol Chem 275: 7230-7238.

Kotsira VP, Clonis YD (1997) Oxalate oxidase from barley roots: purification to homogeneity and study of some molecular, catalytic, and binding properties. Arch Biochem Biophys 340: 239-249.

Leonowicz A, Matuszewska A, Luterek J, Ziegenhagen D, WojtaśWasilewska M, Cho NS, Hofrichter M, Rogalski J (1999) Biodegradation of lignin by white rot fungi. Fungal Genet Biol 27: 175-185. DOI: $10.1006 /$ fgbi.1999.1150.

Laemmli UK (1970) Cleavage of structural proteins during the assembly of the head of bacteriophage T4. Nature 227: 680-685. DOI: $10.1038 / 227680 \mathrm{a} 0$.

Mäkelä M, Galkin S, Hatakka A, Lundell T (2002) Production of organic acids and oxalate decarboxylase in lignin-degrading white rot fungi. Enz Microb Technol 30: 542-549. DOI: 10.1016/S01410229(02)00012-1.

Mäkelä MR, Hildén K, Hatakka A, Lundell TK (2009) Oxalate decarboxylase of the white-rot fungus Dichomitus squalens demonstrates a novel enzyme primary structure and non-induced expression on wood and in liquid cultures. Microbiology 155: 2726-2738. DOI: 10.1099/mic.0.028860-0.

Mäkelä MR, Hildén K, Lundell TK (2010) Oxalate decarboxylase: biotechnological update and prevalence of the enzyme in filamentous fungi. Appl Microbiol Biotechnol 87: 801-814. DOI: 10.1007/s00253010-2650-z.

Moussatche P, Angerhofer A, Imaram W, Hoffer E, Uberto K, Brooks C, Bruce C, Sledge D, Richards NGJ, Moomaw EW (2011) Characterization of Ceriporiopsis subvermispora bicupin oxalate oxidase expressed in Pichia pastoris. Arch Biochem Biophys 509: 100-107. DOI: 10.1016/j.abb.2011.01.022.

Perez FJ, Rubio S (2006) An improved chemiluminescence method for hydrogen peroxide determination in plant tissues. Plant Growth Reg 48: 89-95. DOI: 10.1007/s10725-005-5089-y.

Polak J, Jarosz-Wilkołazka A (2012) Fungal laccases as green catalysts for dye synthesis. Proc Biochem 47: 1295-1307. DOI: 10.1016/j. procbio.2012.05.006.

Pundir CS, Nath R (1984) Occurrence of oxalate oxidase in Sorghum leaves. Phytochemistry 23: 1871-1874. DOI: 10.1016/S00319422(00)84932-8.

Sjöde A, Winestrand S, Nilvebrant N-O, Jönsson LJ (2008) Enzymebased control of oxalic acid in the pulp and paper industry. Enz Microb Technol 43: 78-83. DOI: 10.1016/j.enzmictec.2007.11.014.

Svedružić D, Jónsson S, Toyota CG, Reinhardt LA, Ricagno S, Lindqvist Y, Richards NGJ (2005) The enzymes of oxalate metabolism: unexpected structures and mechanisms. Arch Biochem Biophys 433: 176-192. DOI: 10.1016/j.abb.2004.08.032.

Vaisey EB, Cheldelin VH, Newburgh RW (1961) Oxalate oxidation by an obligately parasitic fungus Tilletia contraversa. Arch Biochem Biophys 95: 66-69.

Velutić M, Sulković VH-T (2000) Characterization of cell wall oxalate oxidase from maize roots. Plant Sci 157: 257-263.

Zhu CX, Hong F (2010) Induction of an oxalate decarboxylase in the filamentous fungus Trametes versicolor by addition of inorganic acids. Appl Biochem Biotechnol 160: 655-664. DOI: 10.1007/s12010-0098571-6. 